The Chittagong Univ. J. B. Sci., Vol. 3(1 \&2): pp. 95-107, 2008.

\title{
MENTAL HEALTH AND SOCIAL SUPPORT
}

MD. NURUL ISLAM* AND KAZI FERDOUS IQBAL

Department of Psychology, University of Chittagong, Chittagong-4331, Bangladesh

\begin{abstract}
The present study was undertaken to investigate the effect of social support on mental health. A total of 100 adult respondents (50 normal, 50 mental patients) of age ranging from 18 to 45 were selected as the sample of the study. The Bangla version of Social Support Scale \& Mental Health Questionnaire or GHQ-12 was used in the study. Three aspects of social support were measured: number of social support (SSN), importance of social support (SSI) and satisfaction of social support (SSS). Results of the present study indicated that normal and mental patients differed significantly from each other in terms of social support. This means that the more the social support the better was the respondents' mental health. The result also indicated that normal people had the better mental health than mental patients. Gender had no significant effect on normal \& mental patients.
\end{abstract}

Key Words: Mental health, Social support.

\section{INTRODUCTION}

Mental Health includes a number of dimensions: self esteem, realization of one's potential, the ability to maintain fulfilling meaningful relationship and psychological well-being (Ryff 1995). Allport's conception of maturity, Jung's formulation of individualization, Maslow's concept of self-esteem and Rogers views of fully functioning were overviewed by Ryff. Ryff conceptualizes and measures well-being as including self acceptance, passive relations with others autonomy, environmental mastery, purpose in life and personal growth. It is clear that such a view of mental health constitutes for more than the mere absence of illness or disorder. Epidemiological researchers showed three perspectives to discuss the causes of mental illness: a) Biological causes: genes, virus attack, and biochemical problem of brain, structure of brain, injury, and physical disability; b) Sociological causes: natural disaster, unemployment, mal-adaptability and lower socio economic status and c) Psychological causes: fear, anxiousness, abnormal

\footnotetext{
${ }^{*}$ Corresponding author
} 
ISLAM \& IQBAL.

feeling and thought, etc. Most people would probably fall for short of optimum mental health including that mental health is not a statistical norm but a goal toward which strive. Consequently, advocates of mental health focus on a broad delivery of mental heath services to the general population not just to the most seriously disturbed people. They also emphasize prevention and education as well as intervention that aid people who have already developed particular type of mental illness.

The term "social support" refers to the process through which help is provided to others. This process is influenced by characteristics of the social environment and individual participants, transactions that occur between participants, the resources that are provided, and participant's perceptions of these transactions and their implications (Encyclopedia of Psychology 2000). Researchers have found that social support, the knowledge that we are part of a mutual network of caring, interested others, enables us to lower our levels of stress and to cope better with the stress we do undergo (Uchino et al. 1999; McCabe et al. 2000). Social support refers to the perceived comfort, caring, esteem, or help a person receives from other people or groups (Cobb 1976, Gentry and Kobasa 1984). This support can come from many different sources- the person's spouse or lover, family, friends, co-workers, physician or community organizations. According to researcher Cobb (1976), people with social support believe they are loved and cared for, esteemed and valued, and part of social network, such as family or community organization, that can provide goods, services and mutual defense in times of need or danger. Social support may be categorized into five: a) emotional, b) esteem, c) tangible \& instrumental, d) informational, and e) network. Social support is an emotional help, advices to coping in any situation, to promote self-dependency or stability, tangible help and information help to support seeker (House 1981, Vaux 1988).

Cramer, et al. (1997) investigated 225 adult people and found that when the relation of mental health and social support is poor then the mental health is also poor for achieving the expected social support. Jou and Fukada (1997) investigated 175 students under 13 universities of Japan. They found that there was a strong relationship between mental stress and expected social support, and the students expecting social support was higher corresponding to higher mental stress. Sharpe and Jacqueline (1997) found that family structure and relationship was significantly related to mental illness in Caribbean families. Financial condition was also related to mental illness. Vinokur and VanRyn (1993) found, in their longitudinal study on the effect of positive and negative social support of 


\section{MENTAL HEALTH \& SOCIAL SUPPORT}

1087 retired people, that negative social support had significant effect on mental health and after the retirement positive social support had significant contribution on the development of mental health. This study was supported by Taylor (1991) and Gottmann \& Krokoff (1989). Valentiner et al. (1994) examined social support effect on coping stressful situation. They investigated 175 college students and found that parents or family members' support helped them to face any negative or crisis situation. Bunk et al. (1993) studied the relation of mental stress and social support of the employees of a mental hospital. They showed that the employees' good relation and support with their higher authorities made them self- confident. Several researches also showed the positive relationship between mental health and perceived and expected social support (Autonucci and Akiyama 1987, Krause et al. 1989, Larocco et al. 1980, Sarason et al. 1993).

Debra (1999) studied the quality of social support in mental and physical health. He found that poor functional support (or quality of support) is related to physical health problems while structural support (or social network size) is not. The results suggest that the quality of social relationships is more important than quality for optimal mental and physical health.

Roquia and Rabeya (1999) studied the attitudes toward mental illness and mental patients of those with and without having a mental patient in the family. The results showed that the two groups of the subjects did not differ significantly on the attitudes toward mental illness but did differ significantly on the attitudes toward mental patients. Patrick et al. (2004) studied perceived stress, internal resources and social support as determinants of mental health among young adults. They showed that mental health was negatively associated with stress and positively associated with internal resources and social support.

Emily and Gharlotte (2006) studied social support, ethnicity and mental health in adolescents. This study identified an independent association between different sources of social support and mental health in a young, ethnically diverse sample. Differences in social support did not explain ethnic differences in psychological distress. Arifa and Shaheen (2006) studied the social support, life stress, coping pattern and mental health. Results of the study indicated that social support was significantly correlated with life stress. Greater satisfaction in social support was found to be related to better mental health.

Taryn et al. (2007) examined the life events and difficulties inherent to the immigration process and the social support that influenced mental health. Social support had neither a main effect on mental health nor a buffer effect on the relationship between life events and difficulties and mental health. Michael et al. (2008) studied social support, activities and recovery from serious mental 
ISLAM \& IQBAL.

illness. They found that both social support and activities may promote recovery and that for persons with poor social support, engagement in a variety of individualized activities may be particularly beneficial.

The present study, therefore, attempts to investigate the effect of social support on the mental health of the respondents.

Objectives of the study-

The objectives of the present study were:

1. To investigate whether social support varies according to types of respondents (normal and mental patients)

2. To investigate whether mental health varies according to gender.

3. To see whether there was any relationship between social support and mental health.

\section{MATERIALS AND METHODS}

\section{Sample}

The present study comprised of 100 adult respondents (50 normal and 50 mental patients). Each group again consisted of 25 male and 25 female respondents. The total number of samples according to gender and types is presented in table-1.

TABLE-1: NUMBER OF STUDY SAMPLE ACCORDING TO GENDER AND TYPES.

\begin{tabular}{lccc}
\hline & \multicolumn{3}{c}{ Types } \\
\cline { 2 - 4 } Gender & Normal & Mental Patients & Total \\
\hline Male & 25 & 25 & \\
Female & 25 & 25 & 100 \\
\hline
\end{tabular}

In the present study, several types of age group were used. The sample of the present study varied according to age as presented in table-2. 
MENTAL HEALTH \& SOCIAL SUPPORT

TABLE-2: NUMBER OF STUDY SAMPLE ACCORDING TO AGE GROUPS.

\begin{tabular}{llccccc}
\hline Age Group & 18-30 Year & $31-45$ Year & $45+$ Year & Total & Grand Total \\
\hline Normal & Male & 20 & 5 & 0 & 25 & \\
& Female & 20 & 4 & 1 & 25 & \\
Mental & Male & 13 & 10 & 2 & 25 & 100 \\
Patients & Female & 16 & 8 & 1 & 25 & \\
\hline
\end{tabular}

Instrument Used

The following instruments were used in the present study:

1) Social Support Scale

2) Mental Health Questionnaire

3) Bio-data Form

\section{Social Support Scale}

The Bangla version (Iqbal 2003) of the social support scale (Pearson 1979) was used to measure the extent of social support. The scale consisted of 12 items. Each item had two 5-point scales-one measured the level of importance and the other level of satisfaction. The importance scale ranged from "very importance" to "no importance". The satisfaction scale ranged from "completely satisfied" to "completely unsatisfied". Lower score in this scale indicates greater importance or greater satisfaction. The scale also measured number of social support by counting the total number of supporters of each participant. The correlation co-efficient of the Bangla version with the English version was found to be 0.63 . The test-retest reliability over a period of week was found to be 0.54 which was significant at .05 level.

\section{Mental Health questionnaire}

Mental health of the respondents measured by the translated and adapted version (Sarker and Rahman 1989) of the original GHQ (General Health Questionnaire) was developed by Goldberg (1972). It is a self administered screening test designed for detecting people with diagnosable psychiatric disorders. The GHQ-12 is concerned with two phenomena: the inability to carry 
ISLAM \& IQBAL.

out one's normal health functions and the new phenomena of a distressing nature. Each item of the scale consists of a question asking whether the respondent has recently experienced a particular symptom of behaviour rated on 4-point scale. Responses were given weights of $0,1,2 \& 3$, respectively. Among the 12 items, 6 were positive and 6 were negative. Positive items were scored in 4-points from 30 and negative items in the reverse order from $0-3$, total score of the scale range from 0-36 with higher score indicating better mental health. The reliability of the Bangla version of the GHQ-12 was measured by parallel form method and was found to be quite satisfactory $(r=0.69)$.

\section{Procedure}

At first the researchers collected the data individually. Mental patients were selected from the Psychiatry Department of BSMMU (Bangabandhu Sheikh Mujib Medical University), Dhaka, and the normal people were selected incidentally. Each respondent was approached personally and given all the questionnaires along with bio data form which included demographic information. All the questionnaires were self administered. They answered the questionnaires by putting tick mark. Permission for research conduction was taken from the authority of the Psychiatry Department of BSMMU and the oral consent was taken from the mental patients of respondents. Respondents and their relatives were ensured by the researchers for the confidentiality of the informed data. Patients who were diagnosed by the psychiatric professionals and staying for treatment at the Psychiatry Department of BSMMU selected as the sample type of mental patient or clinical.

\section{RESULTS AND DISCUSSION}

The present study investigated the effects of social support on mental health. A total of 100 people (50 normal and 50 mental patients) were selected as the sample of the study. Mental health and social support score of the study were analyzed by various statistical analyses such as mean \& standard deviation, correlation and $2 * 2$ ANOVA (Analysis of Variance). 
MENTAL HEALTH \& SOCIAL SUPPORT

TABLE-3: DESCRIPTIVE STATISTICS OF GHQ-12 SCORES ACCORDING TO GENDER AND TYPES.

Gender

Types

\begin{tabular}{lll}
\hline Male & Female & Total
\end{tabular}

Normal

$\bar{X}=30.16$

$\bar{X}=32.00$

$\bar{X}=31.08$

$\mathrm{Sd}=7.94$

$\mathrm{Sd}=6.59$

$\mathrm{Sd}=20.00$

Mental Patients

$\bar{X}=19.24$

$\mathrm{Sd}=3.47$

$\bar{X}=20.76$

$\bar{X}=20.00$

$\mathrm{Sd}=2.7$

$\mathrm{Sd}=3.04$

Total

$\bar{X}=24.70$

$\bar{X}=26.38$

$\mathrm{Sd}=8.20$

$\mathrm{Sd}=7.50$

The study result indicates that there was no significant difference between the male and female score on GHQ-12. But normal and mental patients varied in terms of both male and female respondents. Table-3 shows that normal and mental patient varied in terms of the GHQ-12 score of male respondents (normal, $\bar{X}_{=30.16}$; mental patients, $\bar{X}=19.24$ ) and female respondents (normal, $\bar{X}_{=32.00}$; mental patients, $\bar{X}=20.76$ ). Table also shows that there was difference between normal and mental patient people in their total samples (normal, $\bar{X}=31.08$; mental patients, $\bar{X}=20.00$ ). Thus we can say that the mental health of normal people would have higher than mental patients. These findings were supported by Cramer et al. (1997) and Roquia and Rabeya (1999). We can conclude the causes of the findings: a) in our society attitude toward normal and mental patient are not equal, b) mental illness people are far behind than normal people in regard to every social aspects as well as sociological aspect and c) they do not get proper social support to recovery their mental stress or pressure. 
ISLAM \& IQBAL.

TABLE-4: CORRELATION COEFFICIENT OF GHQ-12 SCORES WITH SSN ${ }^{1}, \mathrm{SSI}^{2}, \& \mathrm{SSS}^{3}$.

\begin{tabular}{lccc}
\hline & \multicolumn{3}{c}{ Social Support } \\
\cline { 2 - 4 } Types & $\mathrm{SSN}^{1}$ & $\mathrm{SSI}^{2}$ & $\mathrm{SSS}^{3}$ \\
\hline Normal & .115 & .333 & $.286^{*}$ \\
Mental Patients & -.026 & $.325^{*}$ & .191 \\
Total & $.468^{*}$ & $.690^{*}$ & .568 \\
\hline *P<.05 & & &
\end{tabular}

The above table indicates that there was a positive correlation between SSI and sample types (normal and mental patients) and SSS and normal people. The table also shows that there was a positive correlation between SSN and SSI. Table-3 shows that there was positive correlation between SSN (Number) and mental health $\left(.468^{*}\right)$. This means that the more the number of social supports the better the mental health. These findings were supported by Emily and Charlotte (2006) and Arifa and Shaheen (2006).

Positive correlation was found between mental health and SSI (Importance) of normal people $\left(.333^{*}\right)$ and mental health and SSI (Importance) of mental patients $\left(.325^{*}\right)$. As a whole, positive correlation was found between mental health and SSI (Importance) of (.690*). If a person has high social support, he/she will have high social importance toward social support (Eric and Thomas 2004). As a result their mental health will be good. The table-3 also indicates that there was positive correlation between mental health and SSS (Satisfaction) of normal people $\left(.286^{*}\right)$. These findings were supported by Jou and Fukada (1997) and Michael et al. (2008).

$\mathrm{SSN}^{1}=$ Social Support Numbers, $\mathrm{SSI}^{2}=$ Social Support Importance, $\mathrm{SSS}^{3}=$ Social Support Satisfaction 
MENTAL HEALTH \& SOCIAL SUPPORT

TABLE-5: MEAN AND STANDARD DEVIATION OF SS SCORES ACCORDING TO GENDER AND SAMPLE TYPE.

Gender

\begin{tabular}{llll}
\cline { 2 - 3 } Types & Male & Female
\end{tabular}

\begin{tabular}{|c|c|c|c|c|c|c|c|c|c|}
\hline & SSN & SSI & SSS & SSN & SSI & SSS & SSN & SSI & SSS \\
\hline \multirow[t]{4}{*}{ Normal } & $\bar{X}=$ & $\bar{X}=$ & $\bar{X}=$ & $\bar{X}=$ & $\bar{X}=$ & $\bar{X}=$ & $\bar{X}=$ & $\bar{X}=$ & $\bar{X}=$ \\
\hline & 4.04 & 48.52 & 42.44 & 3.84 & 47.12 & 43.28 & 3.94 & 47.82 & 42.86 \\
\hline & $\mathrm{Sd}=$ & $\mathrm{Sd}=$ & $\mathrm{Sd}=$ & $\mathrm{Sd}=$ & $\mathrm{Sd}=$ & $\mathrm{Sd}=$ & $\mathrm{Sd}=$ & $\mathrm{Sd}=$ & $\mathrm{Sd}=$ \\
\hline & 1.88 & 7.55 & 7.08 & 1.93 & 6.28 & 5.11 & 1.89 & 6.89 & 6.15 \\
\hline Mental & SSN & SSI & SSS & SSN & SSI & SSS & SSN & SSI & SSS \\
\hline \multirow[t]{6}{*}{ Patients } & $\bar{X}=$ & $\bar{X}=$ & $\bar{X}=$ & $\bar{X}=$ & $\bar{X}=$ & $\bar{X}=$ & $\bar{X}=$ & $\bar{X}=$ & $\bar{X}=$ \\
\hline & 1.60 & 35.88 & 35.72 & 1.88 & 34.84 & 34.40 & 1.74 & 35.36 & 35.06 \\
\hline & $\mathrm{Sd}=$ & $\mathrm{Sd}=$ & $\mathrm{Sd}=$ & $\mathrm{Sd}=$ & $\mathrm{Sd}=$ & $\mathrm{Sd}=$ & $\mathrm{Sd}=1$ & $\mathrm{Sd}=$ & $\mathrm{Sd}=$ \\
\hline & 0.96 & 3.99 & 4.43 & 1.09 & 2.90 & 3.99 & .03 & 3.52 & 4.20 \\
\hline & SSN & SSI & SSS & $\mathrm{SSN}$ & SSI & SSS & & & \\
\hline & $\bar{X}=$ & $\bar{X}=$ & $\bar{X}=$ & $\bar{X}=$ & $\bar{X}=$ & $\bar{X}=$ & & & \\
\hline \multirow[t]{3}{*}{ Total } & 2.82 & 42.20 & 39.08 & 2.86 & 40.98 & 38.84 & & & \\
\hline & $\mathrm{Sd}=$ & $\mathrm{Sd}=$ & $\mathrm{Sd}=$ & $\mathrm{Sd}=$ & $\mathrm{Sd}=$ & $\mathrm{Sd}=$ & & & \\
\hline & 1.92 & 6.87 & 8.66 & 1.84 & 6.60 & 7.68 & & & \\
\hline
\end{tabular}

The above table shows that for three aspects of social support (SSN, SSI $\&$ SSS) there was a difference between normal and mental patient people which means that mentally normal people would have larger number of social supporters than mental patients. Normal people also showed for higher importance of social support and they were highly satisfied than mental patient people. There was no difference according to gender in regard to three aspects of social support. 
ISLAM \& IQBAL.

Table-5 shows the mean and standard deviation of scores in which the normal and mental patients were varied in terms of social support number scores (normal, $\bar{X}=3.94$ and mental patients, $\bar{X}=1.74$ ). As a whole, the score also varied in terms of social support importance (normal, $\bar{X}=47.82$; mental patients, $\bar{X}=35.36$ ) and (normal, $\bar{X}=42.86$; mental patients, $\bar{X}=35.06$ ).

TABLE-6: SSN, SSI AND SSS SCORES ACCORDING TO GENDER AND TYPE OF RESPONDENTS WITH F- VALUES.

\begin{tabular}{|c|c|c|c|c|}
\hline \multirow[b]{2}{*}{ Sources } & \multirow[b]{2}{*}{ of } & \multicolumn{3}{|c|}{ F value of the score } \\
\hline & & SSN & SSI & SSS \\
\hline \multicolumn{5}{|l|}{ Variation } \\
\hline Types & & $51.636^{*}$ & $138.882 *$ & $50.346^{*}$ \\
\hline Gender & & .017 & .251 & .828 \\
\hline Interaction & & .615 & .865 & .328 \\
\hline
\end{tabular}

The study results indicate that three aspects of social support varied according to sample types $\left(\mathrm{F}=51.636^{*}, \mathrm{df}=1, * \mathrm{P}<.05\right)$; social support importance $(\mathrm{F}=138.882 *, \mathrm{df}=1, * \mathrm{P}<.05)$ and social support satisfaction $\left(\mathrm{F}=50.346^{*}, \mathrm{df}=1, *\right.$ $\mathrm{P}<.05)$. This finding was supported by Debra (1999). Gender had no significant effects on three aspects of social support. These findings were supported by Sarason et al. (1993). No significant interaction effect was also found (Taryn et al. 2007).

\section{REFERENCES}

ARIFA R. AND SHAHEEN I. 2006. Social Support, Life Stress, Coping Pattern and Mental Health. Bangladesh Psychological Studies. 16: 93-103.

AUTONUCCI, T. C. AND AKIYAMA, H. 1987. An examination of sex differences in social support among older men and women. Sex Roles: 17: 737-349.

BUNK, B. P., DOOSJE, B. J. , LIESBETH, G. M. AND HOPSTAKEN, E. M. 1993. Perceived reciprocity social support and stress at work: The role 
MENTAL HEALTH \& SOCIAL SUPPORT

of exchange and communal orientation. Journal of Personality and Social Psychology. 65(4): 801-811.

COBB, S. 1976. Social support as a moderator of stress. Psychosomatic Medicine. 38: $300-314$.

CRAMER, D. HENDERSON, S. AND SCOTT, R. 1997. Mental health and desired social support: A four-wave panel study. Journal of Social and Personal Relationship. 14(6):761-775.

DEBRA V. 1999. Quality of social support in mental and physical health. Current Psychology. 18(2): 205-221.

EMILY K. AND GHARLOTTE, C. 2006. Social support, Ethnicity and mental health in adolescencts. Social Psychiatry and Psychiatric Epidemiology. 41(9): 755-760.

GENTRY, W.D. AND KOBASA, S.C.O. 1984. Social and psychological resources mediating stress-illness relationships in humans, In W. D. Gentry (Ed.), Handbook of Behavioral Medicine. New York: Guilford. pp 87-113

GOLDBERG, D. P. 1972. The Direction of Psychiatric Illness by Questionnaire, London. Oxford University Press (Monograph-21).

GOTTMANN, J. M. AND KROKOFF, L. J. 1989. Marital interaction and satisfaction: A longitudinal view. Journal of Counseling and Clinical Psychology. 57: 47-52.

HOUSE, J. 1981. Work stress and social support. Reading, MA: Addisonweseley.

IQBAL, K.F.2003. Mental health and Social Support. Unpublished research project. Department of Psychology, University of Dhaka.

JOU, H. Y. AND FUKADA, H. 1997. Stress on social support in mental and physical health of Chinese students in Japan. Psychological Reports. 81 (3, pt-2): 1303-1312.

KAZDIN, A.E. 2000. Encyclopedia of Psychology. Oxford University Press. 7: 373-375.

KRAUSE, N., LIANG, J. AND YATOMI, N. 1989. Satisfaction with Social Support and depressive symptoms: A panel analysis. Psychology \& Aging. 4: 88-97.

LAROCCO, J. M., HOUSE, J. S. AND FRENCH, J. R. P. 1980. Social support, occupational stress and health. Journal of Health and Social Behavio. 21: 202-218.

MCCABE, P. M., SCHENEIDERMAN, N., FIELD, T. AND WELLENS, A.R. 2000. Stress Coping and cardiovascular diseases. Mahwah, NJ: Erlbaum. 
ISLAM \& IQBAL.

MICHAEL H., CARLA, A.G. AND NANGY, A. P.2008. Social support, Activities and Recovery from Serious Mental Illness. The Journal of Behavioral Services and Research: Regular article.

PATRICK, A.B, ERIC C. AND THOMAS, V.P.2004. Perceived stress, internal resources and social support as determinants of mental health among young adults. Quality of Life Research. 13(1): 161-170.

PEARSON, R. E. 1979. The Personal Support System Survey: Network Structural interactive indices data. Manuscript, Syracuse Uni, Syracuse, New York.

RYFF, C. D. 1995. Psychological well-being in adult life. Current Directions in Psychological Science. 4: 99-104.

ROQUIA BEGUM AND RABEYA SULTANA. 1999. Attitudes Toward Mental Illness and Mental Patients with and without having a Mental Patient in the Family. The Dhaka University Journal of Psycholog. 23: 47-56.

SARASON, B. R., PIERCE, G. R., BANNERMAN, A. AND SARASON, I. G. 1993. Investigating the Antecedents of Perceived Social Support: Parents view and behavior toward their children. Journal of Personality and Social Psychology. 65(5): 1071-1085.

SARKER, N. R. AND RAHMAN, A. 1989. Occupational stress and mental health of working women. UFG, Dhaka.

SHARPE AND JACQUELINE. 1997. Mental health issues and family socializations in the Caribbean families: Diversity among ethnic groups. Advanced in applied development Psychology, vol-14. Roopnarine, Jaipaul, L. \& Brown, J. (Eds.). Ables Publishing Corp: Norwood, NJ.

TARYN, N.T, KEITH O. AND BRENDA, B.T. 2007. The Life Events and Difficulties inherent to the Immigration Process and the social support. Journal of Immigrant and Minority Health. 9(4): 281-290.

TAYLOR, S. E. 1991. Asymmetrical effects of positive and negative events: The mobilization-minimization hypothesis. Psychological Bulletin. 110: 67-85.

UCHINO, B.N., UNO, D. AND HOLT-LUNSTAND, J. 1999. Social support physiological processes and health. Current Directions in Psychological Science. 8: 145-148.

VALENTINER, D. P., HOLAHAN, J. C. AND MOOS, R. H. 1994. Social support, Appraisals of Event Controllability and Coping: An integrative model. Journal of Personality and Social Psychology. 66(6): 1094-1102. 
MENTAL HEALTH \& SOCIAL SUPPORT

VAUX, A. 1988. Social Support: Theory, research, aditervesio. New York. Praeger. pp 307-336

VINOKUR, A. D. AND VANRYN, M. 1993. Social support and undermining in close relationship: Their independent effects on the mental health of unemployed persons. Journal of Personality and Social Psychology. 65(2): 350-359.

Manuscript received on 27.8.08; Accepted on

The Chittagong University Journal of Biological Sciences, Vol. 3( 1 \& 2): pp. 95-107, 2008. 